\title{
Mekanisme Rekrutmen Calon Legislatif Perempuan dalam Pemilihan Legislatif Tahun 2019 (Studi di DPC Partai Kebangkitan Bangsa Kabupaten Malang)
}

\author{
Mahathir Muhammad Iqbal $^{1)}$, Ahmad Syaiful Kurniawan ${ }^{2)}$ \\ 1)2) Program Studi Ilmu Pemerintahan, Universitas Islam Raden Rahmat Malang \\ Jl. Raya Mojosari, No. 02, Kepanjen-Malang, Jawa Timur \\ Email :iqbalz_mm@yahoo.com ${ }^{l)}$, saifulistajr@yahoo.co.id ${ }^{2}$
}

\begin{abstract}
Political parties play a role as a very strategic link between government processes and citizens. Each political party has a different recruitment pattern, where the recruitment pattern of party members is adjusted to the political system it adopts. In recruiting members and candidates for the 2019 legislative elections, DPC of the Malang Regency National Awakening Party provides equal opportunities for all citizens to compete in the selection process of candidates. The theory used is the recruitment of Pippa Norris who uses three indicators, namely: the certification stage, the nomination stage, and the general election stage. The type of approach used is qualitative using the case study method. The results of this study indicate that there are considerations taken by the National Awakening Party DPC to determine female members and candidates based on party regulations regarding the recruitment mechanism of members and candidates. Regarding this, the National Awakening Party DPC gave equal freedom to all citizens, both women and men, to become candidates. This is based on 3 indicators of the recruitment pattern of Pippa Norris, namely: first, the certification stage for candidates, the National Awakening Party DPC provides equal opportunities for everyone to run for party according to party regulations. Second, in the nomination stage, women candidates are given knowledge and skills by being obliged to enter the party underbow organization. Third, the election stage where women candidates are carried by parties to compete in legislative elections. Where women are only used as fulfillment of the 30\% quota of women's representation in 2019 legislative elections
\end{abstract}

Keywords : Recruitment, women, political parties

\begin{abstract}
Abstrak
Partai politik memainkan peran sebagai penghubung yang sangat strategis antara proses-proses pemerintahan dengan warga negara. Setiap partai politik memiliki pola rekrutmen yang berbeda, dimana pola perekrutan anggota partai disesuaikan dengan sistem politik yang dianutnya. Dalam melakukan perekrutan anggota dan Caleg untuk pemilihan legislatif tahun 2019, DPC Partai Kebangkitan Bangsa Kabupaten Malang memberikan kesempatan yang sama kepada seluruh warga negara untuk ikut bersaing dalam proses penyeleksian Caleg. Teori yang digunakan adalah rekrutmen dari Pippa Norris yang memakai tiga indikator, yakni: tahap sertifikasi, tahap nominasi, dan tahap pemilihan umum. Jenis pendekatan yang digunakan adalah kualitatif dengan memakai metode studi kasus Hasil penelitian ini menunjukan bahwa adanya pertimbangan yang diambil oleh DPC Partai Kebangkitan Bangsa untuk menetapkan anggota dan Caleg perempuan berdasarkan peraturan partai tentang mekanisme perekrutan anggota dan Caleg. Perihal ini DPC Partai Kebangkitan Bangsa memberikan kebebasan yang sama kepada semua warga Negara baik perempuan maupun laki- laki untuk menjadi Caleg. Ini berdasarkan 3 indikator pola rekrutmen Pippa Norris yaitu: pertama, tahap sertifikasi terhadap Caleg, DPC Partai Kebangkitan Bangsa menyediakan kesempatan yang sama kepada seтиа orang untuk mencalonkan diri sesuai dengan peraturan partai. Kedua, tahap nominasi, caleg perempuan diberikan pengetahuan dan ketrampilan dengan berkewajiban masuk pada organisasi underbow partai. Ketiga, tahap pemilu dimana caleg perempuan diusung partai untuk bersaing pada pemilihan legsilatif. Dimana perempuan hanya dijadikan sebagai pemenuhan kuota 30\% keterwakilan perempuan dalam pileg 2019.
\end{abstract}

Kata kunci : Rekrutmen, perempuan, partai politik 


\section{Pendahuluan}

Mempunyai orientasi, nilai-nilai, dan cita-cita yang sama. Tujuan kelompok ini ialah untuk memperoleh kekuasaan politik dan merebut kedudukan politik (biasanya) dengan cara konstitusional untuk melaksanakan programnya. Kehadiran partai politik tidak dapat dilepaskan dari fungsi dan perannya untuk mengelola negara. Keberadaan partai politik menjadi keharusan, sebab fungsi utama partai politik adalah bersaing untuk memenangkan pemilihan umum (pemilu), menampung berbagai aspirasi dan kepentingan masyarakat, menyediakan alternative kebijakan, dan mempersiapkan para calon pemimpin yang akan duduk dalam pemerintahan (Miriam Budiardjo, 2010: 403-404). Menurut Ramlan Surbakti (1999: 115) dengan meluasnya gagasan bahwa rakyat harus di ikutsertakan dalam proses politik maka partai politik telah lahir, dan berkembang menjadi penghubung penting antara rakyat dan pemerintah. Bahkan partai politik dianggap sebagai perwujudan atau lambang negara modern. Untuk kepentingan internalnya, setiap partai politik butuh kader - kader yang berkualitas, karena hanya dengan kader yang demikian ia dapat menjadi partai yang mempunyai kesmepatan lebih besar untuk mengembangkan diri. Partai politik juga berhak memperluas atau memperbanyak anggotanya. Maka ia pun berusaha menarik sebanyak - banyaknya orang untuk menjadi anggotanya. Dengan didirikannya organisasi - organisasi massa (sebagai Underbow) yang melibatkan golongan golongan buruh, petani, pemuda, mahasiswa, wanita dan sebagainya, kesempatan untuk berpartisipasi semakin diperluas (Miriam Budiardjo, 2010: 408). Partai politik juga harus didasari basis yang kuat untuk meraih citacita dan tujuan partai politik itu sendiri dalam jangka panjang yang harus dilakukan oleh anggota barunya. Anggota partai politik yang sudah lolos dan menjadi kader partai politik akan bisa menduduki jabatan-jabatan publik dan ikut andil dalam mengambil kebijakan baik itu di tingkat lokal maupun di tingkat nasional (Firmanzah, 2011: 16).

Dalam sistem pemerintahan demokrasi modern saat ini, partai politik sangat dimanjakan dengan adanya kebebasan untuk aktif dan turut serta dalam proses pemerintahan. Salah satu bentuk partisipasi dari partai politik adalah mencetak calon pemimpin tersebut melalui fungsi rekrutmen politik. Seperti yang di ungkapkan oleh Affan Gaffar (2006: 155), proses rekruitmen dapat dilakukan secara terbuka, semi tertutup dan bahkan tertutup. Derajat keterbukaan rekruitmen dipengaruhi oleh derajat pelaksanaan sistem demokrasi suatu negara. Dengan sistem rekruitmen yang terbuka maka masyarakat dapat memilih pemimpin yang memiliki kapasitas dan integritas yang baik serta berakhlak mulia dan memiliki tujuan yang baik.

Dalam undang - undang nomor 2 tahun 2011 tentang partai politik, dimana pasal 2 ayat 4 menyebutkan :

"AD sebagaimana dimaksud pada ayat (3) memuat paling sedikit :

a. asas dan ciri Partai Politik; b. visi dan misi Partai Politik;

c. nama, lambang, dan tanda gambar Partai Politik;

d. tujuan dan fungsi Partai Politik;

e. organisasi, tempat kedudukan, dan pengambilan keputusan;

f. kepengurusan Partai Politik;

g. mekanisme rekrutmen keanggotaan Partai Politik dan jabatan politik;

h. sistem kaderisasi;

i. mekanisme pemberhentian anggota Partai Politik;

j. peraturan dan keputusan Partai Politik;

k. pendidikan politik;

l. keuangan Partai Politik; dan

m. mekanisme penyelesaian perselisihan internal Partai Politik."

Pada poin (g) di atas disebutkan bahwa partai politik harus membuat mekanisme rekrutmen keanggotaan Partai Politik dan jabatan politik yang mana menjadi pedoman untuk merekrut anggota partai politik dengan proses yang di tentukan oleh partai politik itu sendiri.

Begitupun juga, saat partai politik harus memenuhi amanat undang - undang nomor 2 tahun 2011 tentang partai politik, dimana pasal 2 ayat 2 menyebutkan :

"Pendirian dan pembentukan Partai Politik sebagaimana dimaksud pada ayat (1) menyertakan $30 \%$ (tiga puluh persen) keterwakilan perempuan."

Perempuan, manusia yang diciptakan Tuhan selain laki-laki, perempuan memiliki banyak keunikan tersendiri dalam setiap aktifitas hidupnya. Secara kuantitas (jumlah), berdasarkan proyeksi pertumbuhan penduduk Badan Perencanaan Pembangunan Nasioal, Badan Pusat Statistik dan United Nations Population Fund jumlah penduduk Indonesia pada 2018 mencapai 265 juta jiwa. Dari jumlah tersebut, sebanyak 131,88 juta jiwa berjenis kelamin perempuan. Menurut Kamus Besar Bahasa Indonesia (KBBI), perempuan berarti wanita atau istri atau bini. Menurut Abdul Syani (1992: 45) adapun pengertian perempuan sendiri secara etimologis berasal dari kata empu yang berarti "tuan", orang yang mahir atau berkuasa, kepala, hulu, yang paling besar. Namun menurut Zaitunah Subhan $(2004 ; 1)$ perempuan berasal dari kata empu yang artinya dihargai. Sementara itu feminisme perempuan mengatakan, bahwa perempuan merupakan istilah untuk konstruksi sosial yang identitasnya ditetapkan dan dikonstruksi melalui penggambaran.

Menyertakan peran dan partisipasi politik perempuan di partai politik menjadi hal yang mutlak dan wajib dilakukan oleh semua partai politik. Fungsi rekrutmen yang dimiliki oleh partai politik dan dijalankan dengan benar (secara ideal) dapat menjadi pintu masuk sekaligus menjadi faktor pendorong bagi perempuan tentunya untuk bisa menyalurkan aspirasi dan kualitas dari dirinya.

Rekrutmen anggota perempuan yang dilakukan oleh partai politik diperjelas lagi dalam pasal 29 pasal $1-3$ :

"(1) Partai Politik melakukan rekrutmen terhadap warga negara Indonesia untuk menjadi :

a. anggota Partai Politik; 
b. bakal calon anggota Dewan Perwakilan Rakyat dan Dewan Perwakilan Rakyat Daerah;

c. bakal calon kepala daerah dan wakil kepala daerah; dan d. bakal calon Presiden dan Wakil Presiden.

(1a) Rekrutmen sebagaimana dimaksud pada ayat (1) huruf $b$ dilaksanakan melalui seleksi kaderisasi secara demokratis sesuai dengan AD dan ART dengan mempertimbangkan paling sedikit $30 \%$ (tiga puluh perseratus) keterwakilan perempuan.

(2) Rekrutmen sebagaimana dimaksud pada ayat (1) huruf $c$ dan huruf d dilakukan secara demokratis dan terbuka sesuai dengan AD dan ART serta peraturan perundang-undangan.

(3) Penetapan atas rekrutmen sebagaimana dimaksud pada ayat (1), ayat (1a), dan ayat (2) dilakukan dengan keputusan pengurus Partai Politik sesuai dengan AD dan ART."

Peran perempuan juga bisa dilihat dari keikutsertaannya sebagai peserta pemilu dalam hal ini menjadi calon legislatif melalui partai politik di pemilu 2019. Di tegaskan dalam UU Pemilu Nomor 7 tahun 2017 Pasal 173 ayat 2 poin e yang berbunyi :

"Menyertakan paling sedikit 30\% (tiga puluh persen) keterwakilan perempuan pada kepengurusan partai politik tingkat pusat."

Dalam hal itu dapat diartikan bahwa keterwakilan $30 \%$ hanya berlaku di tingkat pusat tidak di tingkat kabupaten/kota, kemudian dalam kepengurusan partai politik di kabupaten/kota hanya berlaku untuk penyusunan daftar calon legislatif sebagaimana Pasal 243 ayat 4 :

"Daftar bakal calon anggota DPRD kabupaten/kota ditetapkan oleh pengurus Partai Politik Peserta Pemilu tingkat kabupaten/kota."

Lalu, ditegaskan dalam Pasal 245 yang berbunyi :

"Daftar bakal calon sebagaimana dimaksud dalam Pasal 243 meтuat keterwakilan perempuan paling sedikit 30\% (tiga puluh persen)."

Dalam melakukan rekrutmen juga ada yang sangat penting dan harus diperhatikan yaitu peran perempuan. Keterlibatan perempuan dalam politik formal di Indonesia mulai memperoleh ruang sejak dikeluarkannya Undang-Undang Pemilu No. 12 Tahun 2003, yang menyebutkan pentingnya aksi afirmasi bagi partisipasi politik perempuan dengan menetapkan jumlah $30 \%$ dari seluruh calon partai politik pada parlemen di tingkat nasional maupun lokal. Aksi afirmasi seringkali didefinisikan sebagai upaya strategis untuk mempromosikan kesamaan dan kesempatan bagi kelompok tertentu dalam masyarakat seperti perempuan atau kelompok minoritas yang kurang terwakili dalam proses pengambilan keputusan.

Perlu diketahui juga, penerapan kebijakan afirmatif dalam tiga pemilu terakhir $(2004,2009$, 2014) menunjukkan adanya pencapaian keterwakilan perempuan di legislatif. Pemilu 1999 yang merupakan pemilu pertama di Era Reformasi dan tanpa afirmasi, jumlah perempuan terpilih di DPR hanya 9\% (46 dari 500). Saat kebijakan afirmasi perempuan pertama kali diterapkan pada Pemilu 2004, terjadi peningkatan jumlah perempuan terpilih di DPR yaitu 65 orang dari 550 anggota DPR (11,8\%). Afirmasi plus (30\% dan penempatan 1 dari 3) pada Pemilu 2009 memberikan hasil yang lebih baik dari sebelumnya. Jumlah perempuan terpilih mencapai persentase tertinggi yaitu 18\% (101 dari 560). Namun, pada Pemilu 2014 dengan aturan afirmasi plus yang sama, jumlah perempuan terpilih di DPR turun menjadi 97 orang (17,3\%).

Partai Kebangkitan Bangsa atau biasa yang di sebut $\mathrm{PKB}$, sebagai partai dengan basis nasionalis religius yang sangat kuat, menjadi partai yang sangat besar dan termasuk dalam "The big five" di jajaran partai besar yang ada di Indonesia pada pemilihan umum tahun 2019.

Grafik 1. Hasil Perolehan Suara Partai Pemilu 2019

\section{Hasil perolehan suara Partai Pemenang Pemilu 2019}

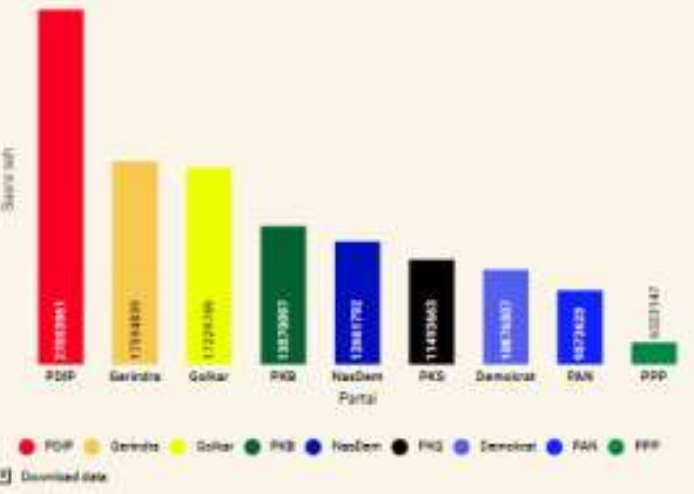

Sumber: KPU tahun 2019

Grafik 1. di atas menunjukkan bahwa dalam pemilu 2019, PKB berada dalam posisi ke Empat dengan perolehan 15.570.097 suara. PDI Perjuangan meraih suara terbanyak dengan 27 juta suara atau 19,33 persen, sementara Partai Gerindra berada di urutan kedua dengan perolehan 17,5 juta suara (12,57\%), mengalahkan Golkar yang ada di peringkat ketiga dengan 17,2 juta suara $(12,31 \%)$.

Tabel 1. Perolehan Kursi Legislatif Pemilu 2019 di Kabupaten Malang

\begin{tabular}{|c|l|c|}
\hline No & \multicolumn{1}{|c|}{ Partai } & $\begin{array}{c}\text { Jumlah } \\
\text { Kursi }\end{array}$ \\
\hline 1. & $\begin{array}{l}\text { Partai Demokrasi Indonesia- } \\
\text { Perjuangan (PDI-P) }\end{array}$ & 12 \\
\hline 2. & $\begin{array}{l}\text { Partai Kebangkitan Bangsa } \\
\text { (PKB) }\end{array}$ & 12 \\
\hline 3. & Golongan Karya (Golkar) & 8 \\
\hline 4. & $\begin{array}{l}\text { Gerakan Indonesia Raya } \\
\text { (Gerindra) }\end{array}$ & 7 \\
\hline 5. & Nasional Demokrat (Nasdem) & 7 \\
\hline 6. & $\begin{array}{l}\text { Partai Pembangunan Bangsa } \\
\text { (PPP) }\end{array}$ & 2 \\
\hline 7. & Partai Demokrat & 1 \\
\hline 8. & Hati Nurani Rakyat (Hanura) & 1 \\
\hline
\end{tabular}

Sumber: KPUD Kabupaten Malang, 2019 
Tabel 1. di atas menyebutkan bahwa Dewan Pengurus Cabang Partai Kebangkitan Bangsa (DPC PKB) Kabupaten Malang dalam pemilihan legislatif tahun 2019 mendapatkan 12 kursi legislatif (DPRD Kabupaten Malang) dari 7 daerah pemilihan (dapil) di Kabupaten Malang, bersaing dengan Partai Demokrasi Indonesia Perjuangan (PDI-P) yang sama memperoleh 12 kursi. Namun, dari 12 kursi legislatif yang di peroleh PKB tersebut hanya ada satu perempuan yang menjadi anggota legislatif dan selebihnya di kuasai oleh laki laki. Anggota legislatif perempuan tersebut adalah Masfufah dari dapil 1.

Padahal jika dilihat dari pemenuhan peran dan partisipasi politik perempuan dari Partai Kebangkitan Bangsa Kabupaten Malang sebagai bentuk pelaksanaan demokrasi dalam Daftar Calon Tetap (DCT) Bakal Calon Anggota DPRD di Kabupaten Malang dalam pelaksanaan Pemilu dan Pileg tahun 2019 sebesar 48\%. Dan sudah melebihi ambang batas $30 \%$ keterwakilan perempuan sesuai UU Pemilu No. 7 tahun 2017. Jumlah itu bisa di lihat dalam tabel berikut.

Tabel 2. Daftar Calon Tetap (DCT) Bakal Calon Anggota DPRD Kabupaten Malang di Pemilu 2019

\begin{tabular}{|c|c|c|c|c|c|}
\hline \multirow{2}{*}{$\begin{array}{l}\text { No. } \\
\text { Urut }\end{array}$} & \multirow{2}{*}{$\begin{array}{l}\text { Partai } \\
\text { Politik }\end{array}$} & \multirow{2}{*}{$\begin{array}{c}\text { Jumla } \\
\text { h } \\
\text { Bakal } \\
\text { Calon } \\
\text { Legisla } \\
\text { tif } \\
\end{array}$} & \multicolumn{2}{|c|}{$\begin{array}{c}\text { Jenis } \\
\text { Kelami } \\
\mathbf{n} \\
\end{array}$} & \multirow{2}{*}{$\begin{array}{c}\% \\
\text { Keterwa } \\
\text { kilan } \\
\text { Peremp } \\
\text { uan }\end{array}$} \\
\hline & & & $\mathbf{L}$ & $\mathbf{P}$ & \\
\hline 1 & $\begin{array}{l}\text { Partai } \\
\text { Kebangkitan } \\
\text { Bangsa }\end{array}$ & 50 & 26 & 24 & $48 \%$ \\
\hline 2 & $\begin{array}{l}\text { Partai } \\
\text { Gerakan } \\
\text { Indonesia } \\
\text { Raya }\end{array}$ & 48 & 27 & 21 & $44 \%$ \\
\hline 3 & $\begin{array}{l}\text { Partai } \\
\text { Demokrasi } \\
\text { Indonesia } \\
\text { Perjuangan }\end{array}$ & 50 & 29 & 21 & $42 \%$ \\
\hline 4 & $\begin{array}{l}\text { Partai } \\
\text { Golongan } \\
\text { Karya }\end{array}$ & 50 & 29 & 21 & $42 \%$ \\
\hline 5 & $\begin{array}{l}\text { Partai } \\
\text { Nasdem }\end{array}$ & 50 & 29 & 21 & $42 \%$ \\
\hline
\end{tabular}

Sumber : KPU Kabupaten Malang, 2019

Secara teoritik rekrutmen, menggambarkan faktorfaktor utama yang mempengaruhi proses rekrutmen partai politik untuk pencalonan dalam pemilu.

Terbagi atas tiga tahap yakni sertifikasi, nominasi, dan pemilu. Sertifikasi ini termasuk di antaranya aturan hukum pemilu, aturan partai, dan norma sosial yang bersifat informal yang mendefinisikan kriteria kandidat yang dapat dicalonkan dalam pemilu tahun 2019 oleh DPC PKB. Nominasi adalah ketersediaan calon untuk dinominasikan dan proses di mana penyeleksi calon menentukan siapa yang akan dicalonkan dalam pemilu. Pemilu adalah langkah terakhir dimana kandidat memenangkan jabatan publik untuk mewakili DPC PKB di kursi pemerintahan (legislatif).

Berdasarkan pemaparan latar belakang secara singkat di atas, maka peneliti ingin mengetahui bagaimanakah proses rekrutmen partai politik untuk perempuan dalam menghadapi pemilihan legislatif tahun 2019 di Dewan Pengurus Daerah Partai Kebangkitan Bangsa (DPC PKB) Kabupaten Malang dengan judul "Mekanisme Rekrutmen Calon Legislatif Perempuan dalam Pemilihan Legislatif Tahun 2019 di Kabupaten Malang (Studi di DPC Partai Kebangkitan Bangsa Kabupaten Malang)".

\section{A. Metode Penelitian}

Jenis metode penelitian yang digunakan adalah metode kualitatif dengan menggunakan metode studi kasus. Lokasi penelitian berada di Kabupaten Malang. Penelitian berfokus pada mekanisme rekrutmen dan pengusulan calon legislatif perempuan dengan menggunakan 3 tahap rekrutmen calon kandidat, yakni tahap sertifikasi, tahap pencalonan, dan tahap pemilihan umum yang digunakan oleh Dewan Pengurus Cabang Partai Kebangkitan Bangsa dalam pemilihan legislatif tahun 2019 di kabupaten Malang. Pengumpulan informasi dipilih dari narasumber atau informan yang ada di Dewan Pengurus Cabang Partai Kebangkitan Bangsa Kabupaten Malang, KPUD Kabupaten Malang, dan Calon Legislatif Perempuan terpilih dari DPC PKB. Jenis data yang digunakan adalah data primer dan data sekunder. Teknik pengumpulan data di peroleh dari proses wawancara.

\section{Pembahasan}

Tertuang dalam pasal 1 UU No 2 Tahun 2011 jo pasal 1 UU No 2 Tahun 2008 tentang Partai Politik yang kemudian disebut dengan Parpol menyebutkan bahwa "Partai Politik adalah organisasi yang bersifat nasional dan dibentuk oleh sekelompok warga negara Indonesia secara sukarela atas dasar kesamaan kehendak dan citacita untuk memperjuangkan dan membela kepentingan politik anggota, masyarakat, bangsa dan negara, serta memelihara keutuhan Negara Kesatuan Republik Indonesia berdasarkan Pancasila dan UndangUndang Dasar Negara Republik Indonesia Tahun 1945". Dari sinilah kemudian parpol menjadi kedudukan dan mempunyai peranan sentral dalam sistem demokrasi. Demokrasi yang dalam artian bahwa suara dan pendapat kebebasan rakyat sangat di hormati.

Dari kebebasan berpendapat dan berkumpul ini muncul multi partai atau banyaknya partai lebih dari satu menjadi pertanda salah satu hasil dari reformasi kebebasan tersebut dengan asas dan ciri masing-masing parpol. Undang-undang kepartaian telah memperbolehkan berdirinya partai dengan berbagai asas dan ciri dengan tetap harus mengakui satu-satunya asas negara, yakni Pancasila. Partai-partai yang baru lahir juga banyak bermunculan dan dideklarasikan bahkan tampil dalam berbagai kesempatan untuk mempropagandakan ide-ide dan program-program 
mereka. Ratusan partai telah berdiri dan berusaha mendaftarkan diri ke Departemen Kehakiman untuk mendapatkan pengesahan. Tidak ketinggalan media massa sebagai alat pengarah dan penggiring massa mengikuti gejala pluralitas, partai itu pun dengan masing-masing menekankan dan menonjolkan partai atau tokoh partai yang cenderung didukungnya.

Di masa transisi politik saat ini, nampaknya sistem multipartai masih akan menjadi idola dan bertahan lama. Pasalnya, selain konstitusi menjamin kebebasan berserikat dan berkumpul, para elit politik juga gemar menginstitusionalisasikan dirinya kedalam bentuk parpol. Karena partai politik merupakan kendaraan untuk sampai pada kekuasaan. Di Indonesia regulasi mengenai kebijakan afirmatif terhadap perempuan di arena politik diadopsi lewat UU No.31/2002 tentang Partai Politik dan UU No. 12/2003 untuk Pemilu 2004, serta UU No. 2/2008 tentang Partai Politik dan UU No.10/2009 untuk pemilu 2009. Disini terlihat dari hasil pemilu bahwa ketika setelah terjadi perubahan perempuan yang menduduki jabatan di pemerintahan semakin bertambah. Dimana pada temuan data kuantitatif hasil Pemilu Legislatif 2009 di Indonesia menunjukkan peningktan di tingkat lokal maupun nasional yang dimana berawal dari $11 \%$ menjadi 18\% (100 perempuan dari total 2005 anggota DPR RI) kemudian pada tingkat Provinsi naik dari $10 \%$ menjadi $16 \%$ (dari 321 perempuan dari 2005 anggota DPRD Provinsi dan dari 5\% menjadi $12 \%$ ditingkat Kabupaten/Kota (1.875) perempuan dari total 15.758 anggota DPRD Kabupaten/Kota (Ani Widyani Soetjipto. 2011:44-45).

Dari data di atas menunjukkan bahwa setelah terjadi perubahan undang-undang Partai Politik maupun Undang undang Pemilihan Umum langsung terlihat peningkatan atas jumlah keterwakilan perempuan. Kemudian peningkatan dari jumlah tersebut tidak hanya efek dari peraturan afirmatif akan tetapi juga terkadung dalm demokrasi internal partai yang tertera dalam Anggaran Dasar Anggaran Rumah Tangga Partai (AD/ART), yang sudah di bentuk partai dengan memperhatikan undang-undang yang terkait seperti halnya dalam UU No.2 Tahun 2011 perubahan atas UU No. 2 Tahun 2008 tentang Partai Politik pasal 2 ayat 2 "Pendirian Partai Politik sebagaimana ayat 1 menyertakan 30\% keterwakilan perempuan" dan pasal 2 ayat 5 "Kepengurusan Partai Politik ditingkat pusat dimaksud ayat 2 disusun dengan menyertakan paling sedikit $30 \%$ keterwakilan perempuan". Disini sudah diberlakukan $30 \%$ keterwakilan perempuan pada kepengurusan partai pada tingkat pusat hingga cabang. Selanjutnya karena pembahasan ini berbasis gender terhadap keterwakilan perempuan akan membahasan mengenai gender dan hak-hak yang dimiliki oleh perempuan. Kata-kata gender terkadang masih terasa bias di kalangan masyarakat dan ada pula yang kontra terhadap gender, tapi kebanyakan orang masih salah pemahaman mengenai hal tersebut. Jikalau orang membicarakan mengenai gender akan disangkutkan dengan kesamaan gender padahal disini bukan bermakna kesamaan tapi kesetaraan gender, karena kalau kesamaan gender akan menjadi pengertian yang dimana perempuan harus sama dengan laki-laki dan secara kodrat memang perempuan dan laki-laki berbeda, jikalau kesetaraan ada hal-hal tertentu yang bisa dilakukan oleh laki-laki tapi juga bisa dilakukan oleh perempuan.

Dalam wawancara dengan Muslimin selaku Sekretaris DPC PKB Kabupaten Malang pada Rabu tanggal 2 Oktober 2019, menyampaikan bahwa:

"Untuk mekanisme perekrutan anggota perempuan tidak ada bedanya dengan perekrutan anggota laki-laki, hanya dimana partai dalam hal ini wajib menjalankan amanah undang-undang yang menyatakan bahwa partai politik harus memperhatikan pemenuhan kuota dari $30 \%$ keterwakilan perempuan yang masuk dalam pengurus atau anggota partai dan sebagai calon legislatif".

Dalam tahap sertifikasi (Certification Stage), mengenai jenis keanggotaan PKB sesuai dengan Anggaran Dasar Rumah Tangga pasal 3 yakni :

1. Anggota langsung adalah setiap warga negara Indonesia yang telah terdaftar secara sah menjadi anggota Partai pada Dewan Pengurus Cabang setempat dan secara aktif melakukan tugas-tugas kepartaian serta mengikuti kegiatan-kegiatan Partai.

2. Anggota tidak langsung adalah warga negara Indonesia yang belum/tidak terdaftar secara sah menjadi anggota Partai pada Dewan Pengurus Cabang setempat dan secara aktif mengikuti kegiatankegiatan partai.

3. Anggota kehormatan adalah setiap orang yang dianggap telah berjasa kepada Partai atau orangorang tertentu yang dipilih dan disetujui penetapannya dalam Rapat Pleno Dewan Pengurus Pusat yang mekanismenya akan diatur dalam Peraturan Partai.

Kemudian syarat-syarat untuk menjadi anggota dalam Anggaran Dasar Rumah Tangga pasal 4 yakni :

1. Warga negara Indonesia yang telah berumur 17 tahun dan/atau telah menikah.

2. Dapat membaca dan menulis.

3. Menyetujui dan menerima Anggaran Dasar, Anggaran Rumah Tangga, dan platform Partai.

Kemudian tata cara pendaftaran untuk menjadi anggota partai sesuai Anggaran Dasar Rumah Tangga pasal 5 yakni :

1. Mengajukan permohonan sebagai anggota kepada Dewan Pengurus Cabang, disertai pernyataan persetujuan terhadap Anggaran Dasar, Anggaran Rumah Tangga, dan Peraturan Partai.

2. Permohonan menjadi anggota dapat ditolak apabila terdapat unsur/alasan yang kuat secara organisatoris dan tidak bertentangan dengan Anggaran Dasar dan Anggaran Rumah Tangga.

3. Tatacara pendaftaran anggota diatur dalam Peraturan Partai.

Muslimin juga menambahkan bahwa :

"Setelah menjadi anggota tahap selanjutnya menjadi pengurus dengan syarat yakni pengurus partai disemua tingkatan, seseorang dalam kurun waktu 3 (tiga) tahun terakhir tidak pernah dijatuhi hukuman atas satu tindak pidana yang sudah berkekuatan hukum tetap." 
Mengenai proses rekrutmen dalam tahap sertifikasi (Certification Stage), yang dilakukan oleh Dewan Pengurus Cabang Partai Kebangkitan Bangsa (DPC PKB) Kabupaten Malang melakukan rekrutmen anggota minimal 1 (Satu) tahun 5 (Lima) kali dilakukanya rekrutmen yang dimana termasuk rekrutmen resmi dan wajib yang dilakukan oleh setiap Dewan Perwakilan Cabang (DPC).

Dalam proses rekutmen dalam tahap sertifikasi (Certification Stage), yang dilakukan oleh partai PKB yakni melalui pendaftaran resmi yang dibuka oleh internal DPC PKB sendiri. Setelah melakukan pendaftaran intern, partai akan melakukan dua proses tahapan pertama, pelatihan yakni terdiri atas :

1. Seleksi berkas, jika berkas tidak terpenuhi satu berkas pun maka akan menjadi pertimbangan penilaian terhadap calon tersebut,

2. Interview, interview dilakukan oleh pengurus yang telah ditugaskan oleh partai untuk mewawancarai calon dengan kriteria-kriteria yang sudah ditentukan oleh kesepakatan partai,

3. Di wajibkan untuk mengikuti semua rangkaian acara jika kurang dari itu juga akan mempengaruhi nilai dari calon tersebut.

Untuk calon yang sudah lolos dari tahap pelatihan belum tentu akan lulus pada tahap kedua atau terkahir untuk menjadi anggota karena ada beberapa penilaian, tahap kedua, yakni :

1. Harus lulus dari tahap pertama pada pelatihan,

2. Administrasi,

3. Warga Negara Indonesia (WNI),

4. Menyatakan Ketersediaan secara formal (dalam bentuk surat), serta syarat yang ditentukan oleh pengurus partai misalnya keaktifan dalam partai serta faktor yang lain.

DPC PKB Kabupaten Malang dalam melakukan rekrutmen untuk perempuan diberikan kuota khusus juga dengan menerapkan dan memperhatikan kuota khusus $30 \%$ (tiga puluh persen) keterwakilan perempuan dalam pelaksanaan rekrutmen. Dan ada yang khusus lagi terkait perekrutan anggota partai yakni dengan merekrut anggota dari Organisasi di bawah naungan Nahdlatul Ulama (NU) seperti Muslimat dan Fatayat.

Memang seharusnya dalam proses rekrutmen anggota partai politik mestinya dilakukan secara terencana, dengan tim rekrutmen yang kompeten dan dana yang telah disiapkan dengan matang serta target rekrutmen yang jelas, sehingga mereka yang akan direkrut sesuai dengan kebutuhan partai. Dalam konteks pemilu, kebutuhan partai dalam rekrutmen kandidat sering kali tidak terencana dengan baik. Partai tidak mungkin mengurusi seluruh aspirasi dan kepentingan segenap masyarakat, oleh karena itu partai politik lebih mewakili, merepresentasikan dan memperjuangkan aspirasi dan kepentingan sebagai masyarakatnya saja. Sehingga dari pada itu, fungsi partai politik saat proses rekrutmen anggota partai politik tidak hanya mementingkan kuantitas saja tetapi juga penting melihat dan menakar kualitas calon anggota tersebut.
Di dalam kehidupan masyarakat, dengan didirikannya organisasi - organisasi massa yang melibatkan banyak golongan, seperti golongan para buruh, petani, pemuda, mahasiswa, perempuan, dan sebagainya, kesempatan untuk melakukan perekrutan anggota yang berkualitas dan berintegritas. Rekrutmen politik menjamin keberlangsungan dan kelestarian partai itu sendiri, sekaligus merupakan salah satu cara untuk menyeleksi calon - calon pemimpin. Dengan gerakan organisasi Underbow yang dimiliki oleh DPC PKB Kabupaten Malang, seharusnya bisa menarik minat masyarakat umum dan elit organisasi untuk tergiur ikut menjadi bagian dari anggota partai politik. Maka, tidak hanya merekrut dari kalangan organisasi di bawah naungan Nahdlatul Ulama (NU) saja.

Dalam proses rekutmen dalam kaitannya dengan teori rekrutmen dari Pippa Norris, bahwa di dalam tahap nominasi (nomination stage) Parpol memiliki beberapa peran :

1. Mencalonkan kandidat di dalam proses pemilu.

2. Memberikan jaringan sosial (konstituen dan elemen pendukung lainnya).

3. Training dan pelatihan peningkatan kapasitas.

4. Pengalaman organisasi berpartai yang meningkatkan kapasitas dalam pembuatan kebijakan dan lainnya Senada dengan yang disampaikan oleh Muslimin :

"Dalam meningkatkan keahlian dan kualitas para kader dan anggota partai, di DPC PKB Kabupaten Malang mempunyai 3 (tiga) Banom (Badan Otonom), yang di maksud Badan Otonom disini adalah badan-badan atau lembaga-lembaga yang di bentuk di bawah partai yang mempunyai tugas dan fungsi masing-masing”.

Ketiga lembaga tersebut, yakni :

1. Garda Bangsa (Gerakan Pemuda Bangsa)

Garda Bangsa dimaksudkan untuk menggalang dukungan massa pemilih pemuda. Sekaligus juga menyiapkan politisi - politisi yang nantinya akan meneruskan regenerasi di PKB. Sejak Gus Dur menjabat sebagai Presiden RI yang ke empat, hasrat kaum muda untuk terlibat dalam politik semakin kuat. Begitupun juga di Garda Bangsa PKB Kabupaten Malang. Dan saat ini, Garda bangsa juga sangat intens dan fokus terhadap para pemuda sekolah tingkat SLTA dan sederajat dimana terdapat sosialisasi mengenai pemilih pemula yang cerdas selain itu juga terdapat sosialisasi anti narkoba dan pelatihan-pelaihan yang lain untuk anak muda. Garda Bangsa DPC PKB Kabupaten Malang di ketua oleh H. Mahrus Ali.

2. Gemasaba (Gerakan Mahasiswa Satu Bangsa)

Gemasaba DPC PKB Kabupaten Malang di ketua oleh Syamsul Arifin. Gemasaba sebagai organisasi sayap kemahasiswaan Partai Kebangkitan Bangsa yang bertujuan menghimpun, menggerakkan dan memberdayakan mahasiswa dalam upaya mengawal demokrasi, penegakan hukum yang berpihak kepada keadilan rakyat, dan upaya mencapai cita-cita luhur bangsa Indonesia dalam mengemban amanat luhur Partai Kebangkitan Bangsa. Gemasaba ini lebih berfokus pada mahasiswa, acara yang dilakukan seperti pelatihan, kemudian ada gerakan media sosial yang dilakukan 
partai untuk memberikan sosialisasi melalui media sosial. Partai sangat mengapresiasi mahasiswa karena partai mengangap sangat membutuhkan pemikiranpemikiran kritis pemuda mahasiswa. Dalam kepengurusan Gemasaba ini pengurus di dominasi oleh kaum laki-laki.

\section{Perempuan Bangsa}

Sebagai sayap pergerakan dan kaderisasi Partai yang berfokuskan pada gender perempuan, maka pemenuhan keterwakilan $30 \%$ perempuan di tubuh partai, perempuan Bangsa sangat dibutuhkan eksistensinya dan partisipasinya. Perempuan bangsa umumnya di anggotai oleh perempuan, banyak acara yang di adakan oleh para perempuan bangsa ini seperti penyuluhan dan sosialisasi. Pada perempuan bangsa ini juga mempunyai grup paduan suara dan grup arisan yang di harapkan menjadi pengerat antar kader. Kemudian dalam acara event lainnya, tidak menutup kemungkinan perempaun non kader juga diperbolehkan untuk mengikuti kegiatan ini. Perempuan Bangsa DPC PKB Kabupaten Malang di ketua oleh Hernganti Ika Anggraina, S. Pd

Alur tahapan proses rekrutmen anggota sebagaimana peraturan dan juklak serta juknis dari partai kebangkitan bangsa kabupaten Malang bisa dilihat dalam gambar 1 . Dalam proses sertifikasi (Certification Stage) dan nominasi (Nomination Stage) terkait rekrutmen angggota partai, PKB sudah melakukan sebagaimana amanah undang - undang dan peraturan partai, dengan di awali membuka pendaftaran umum secara resmi sampai tahap penilaian calon anggota tersebut layak atau tidak. Namun terkait calon anggota perempuan tidak ada perlakuan khusus terhadap proses rekrtumen menjadi anggota partai politik.

\section{Kesimpulan}

Dari hasil pembahasan tentang rekrutmen perempuan yang dilakukan oleh partai politik untuk partai sendiri dan calon perempuan untuk mengikuti dan menjadi calon angggota legislatif di pemilihan legislatif kabupaten Malang tahun 2019 pada bab sebelumnya bisa ditarik kesimpulan, yaitu :

1. Proses rekrutmen dalam tahap sertifikasi (certification stage) untuk calon anggota partai perempuan yang dilakukan oleh DPC PKB Kabupaten Malang memiliki tahap lebih banyak, yakni :

a. Partai membuka pendaftaran

b. Calon mengajukan permohonan sebagai anggota

c. Permohonan bisa ditolak atau diterima

d. Seleksi berkas oleh partai

e. Interview

f. Mengikuti serangkaian kegiatan

g. Calon yang sudah lulus harus mengikuti tahap kedua

h. Penilaian

Pada tahap kedua lolos lalu membuat surat pernyataan formal ketersediaan dalam mengikuti kegitan partai. Dalam tahap nominasi (nomination stage), DPC PKB Kabupaten Malang terdapat pada sayap-sayap atau organisasi Underbow partai yakni :

a. Gerakan Pemuda Bangsa (Garda Bangsa) b. Gerakan Mahasiswa Satu Bangsa (Gemasaba)

c. Perempuan Bangsa, sayap khusus untuk perempuan terdapat pada sayap perempuan bangsa yang dimana kegiatan yang mereka kerjakan adalah melakukan penyuluhan dan sosialisasi selain itu para anggota perempuan juga mempunyai beberapa grup kegiatan seperti pduan suara untuk lebih mengeratkan rasa kekeluargaan.

Di DPC PKB Kabupaten Malang sangat detail dalam pemberkasan. Kemudian, dalam rekrutmen antara lakilaki dan perempuan sama rata tidak ada perbedaan dalam jumlah laki-laki dan perempuan juga tidak ada batasan jumlah, siapa yang berminat dipersilahkan untuk mendaftarkan diri. Hanya saja, DPC PKB Kabupaten Malang lebih mementingkan yang kader partai. Lalu selebihnya akan merekrut dari organisasi yang berafiliasi dengan partai yakni Muslimat dan Fatayat NU.

DPC PKB Kabupaten Malang dalam tiga tahap rekrutmen (tahap sertifikasi, tahap nominasi, dan tahap pemilihan umum), petinggi partai mempunyai suara kuat dalam pemilihan calonnya. Penilaian calon dari Caleg bisa dipastikan terletak dari pemberkasan (administrasi) dan suara dari petinggi partai. Dalam hal pendaftaran, DPC PKB Kabupaten Malang tidak membatasi dalam jumlah khusus untuk perempuan maupun laki-laki. Akan tetapi dalam kenyataanya meskipun dalam keterwakilan perempuan $30 \%$ sudah terpenuhi di semua dapil, tapi masih lemah peran perempuannya seakan akan hanya untuk formalitas dalam memenuhi kuota keterwakilan perempuan. Dan demokrasi internal partai yang sudah disusun sedemikian rupa belum dijalankan sesuai dengan sebagaimana mestinya, terkadang partai mengusung calon yang bukan dari partainya, adapun nama perempuan dalam daftar hanyalah sebuah nama yang berharga untuk memenuhi dari segala peraturan, peraturan dari partai sendiri maupun dari undang-undang yang berlaku dan partai akan lebih mengusung calon yang dianggap mempunyai suara tiinggi di masyarakat dari hasil survey.

\section{Saran}

Dalam aturan-aturan yang dimiliki partai memang begitu menjanjikan khusus untuk perempuan misalnya dalam memenuhi kepungurusan partai harus memenuhi kuota $30 \%$ perempuan akan tetapi tetap saja perempuan masih sekedar nama. Kemudian yang dilakukan kebanyakan partai hanya melakukan pendidikan, sosialisasi dan penyuluhan partai yang terkadang hanya sesaat. Seharusnya partai sering melakukan sosialisai mengenai partai politik yang bersasaran tidak hanya pada kalangan perempuan di bidang tertentu saja misalnya kalangan perempuan yang hanya mengandalkan materi dan keturunan kyai atau tokoh daerah. Menurut penulis perlu di lakukan juga dalam kalangan masyarakat perempuan luas, bisa tokoh di pedesaan yang punya pengaruh dan prestasi yang luar biasa, meskipun mereka terkait materi kurang dan bukan keturunan tokoh atau kyai, akan tetapi dengan berbagai kemajuan zaman dan informasi pasti masyaakat desa 
juga tidak kalah dalam partisipasi, disamping partai melakukan penyuluhan dan sosialisasi seharusnya partai juga lebih intens dalam melakukan pendampingan terhadap anggota perempuan agar perempuan mempunyai kualitas yang bagus untuk menjadi anggota partai bukan perempuan sebatas nama. Selain itu yang tidak kalah penting juga adalah faktor dari perempuan itu sendiri yang mempunyai banyak kegitan domestik terkadang merasa tidak penting untuk ikut partisipasi dalam politik

\section{Daftar Pustaka}

Almond, Gabriel dan Powel, Jr, G. Bingham. 1978. Comparative Politics: Sistems, Process, and Policy. Second Edition. Boston : Little Brown and Company.

Budiardjo, Miriam. 1982. Partisipasi dan Partai Politik Sebuah Bunga Rampai. Jakarta: Gramedia Pustaka Utama.

Budiardjo, Miriam. 2008. Dasar - dasar Ilmu Politik. Edisi Revisi. Jakarta: Gramedia Pustaka Utama.

Firmanzah. 2008. Mengelola Partai Politik . Komunikasi dan Positioning Ideologi Politik di Era Demokrasi. Jakarta: Yayasan Obor Indonesia.

Haboddin, Muhtar dan Arjul. Muh. 2016. Pengantar Ilmu Politik. Malang: UB Press

Haboddin, Muhtar. 2016. Pemilu dan Partai Politik di Indonesia. Malang: UB Press

Hazan, Reuven Y. 2006. Candidate Selection : Methods And Consequences, dalam Richard S. Katz dan William Crotty, Handbook of Party Politics. London : Sage Publication.

Horrison, Lisa. 2007. Metodologi penelitian politik. Jakarta: Kencana Prenada Media Group

Huntington, Samuel P. dan Nelson, Joan. 1994. Partisipasi Politik di Negara Berkembang. Jakarta: Rineka Cipta.

Moleong, Lexy J. 2017. Metodologi Penelitian Kualitatif. Bandung: PT. Remaja Rosdakarya.

Norris, Pippa. 2006. Recruitment, dalam Richard S. Katz dan William Crotty, Handbook of Party Politics. London : Sage Publication.

Pamungkas, Sigit. 2011. Partai Politik: Teori dan Praktik di Indonesia. Yogyakarta : Institute for Democracy and Welfarism.

Soetjipto, Ani Widyani. 2011. Politik Harapan: Perjalanan Politik Perempuan Pasca Reformasi. Tangerang: Marjin Kiri.

Sugiyono. 2016. Metode Penelitian Kuantitatif, Kualitatif, dan $R \& D$. Bandung: Alfabeta CV.

Surbakti, Ramlan. 1999. Memahami Ilmu Politik. Jakarta: PT. Grasindo

Yin, Robert K. 2005. Studi Kasus Design \& Metode. Jakarta: Rajawali Pers.

A. Peraturan Perundang - Undangan

Undang - Undang Dasar Negara Kesatuan Republik Indonesia Tahun 1945.
Undang - Undang Dasar Nomor 7 Tahun 2017 pasal 10 ayat 7 tentang pemilihan umum.

Undang - Undang Dasar Nomor 12 tahun 2003 pasal 65 tentang pemilihan umum.

Undang - Undang Dasar Negara Republik Indonesia Tahun 1945 Nomor 2 tahun 2011 tentang Partai Politik.

Anggaran Dasar dan Anggaran Rumah Tangga Partai Kebangkitan Bangsa (PKB)

DPP PKB. 2019. Anggaran Dasar/Anggaran Rumah Tangga (AD/ART) Partai

Kebangkitan Bangsa: Hasil Muktamar Partai Kebangkitan Bangsa di Surabaya 30 Agustus - 1 September 2014. Jakarta: Sekretariat Jendral DPP PKB.

B. Website

www.kpud-malangkab.go.id

www.pkb.id 